\title{
INITIATION AND IMPLEMENTATION: CHANGES TO TEACHER EDUCATION IN IRELAND
}

\author{
Rose Dolan
}

\begin{abstract}
Fullan (1991) described the process of change as having four broad phases: initiation, implementation, continuation and outcome. The education system in Ireland has undergone unprecedented change since the Education Act of 1998 and most particularly with the formation of the Teaching Council in 2006. Since 2011, the Council has produced four policy documents, a revised code of conduct and at least three documents relating to procedures and requirements for admission to ITE and registration upon completion of ITE, all relating to the profession of teaching in Ireland, This has resulted in a period of immense change for University education departments and for colleges of education. Much of the change is still situated in the initiation and early implementation phases. This paper provides a context for those changes, outlines how they came to pass and considers the implications of so much change within a system in a short period of time, It looks at the effects of these changes on those who aspire to be teachers in Ireland in the second decade of the $21 \mathrm{st}$ century.
\end{abstract}

Key words: Initial Teacher Education (ITE), induction, policy development, change.

\section{INTRODUCTION}

In 1998, the Education Act passed into Irish law. This was a significant moment in the Irish education system as it was the first education act to be passed since the formation of the Irish Republic. It arose from significant public consultation through the National Education Convention of 1993, following the publication of a Green Paper in 1992, and has provided, for the first time, a statutory framework for the Irish Education system that clarifies the roles and responsibilities of the various stakeholders in the system. The consultations also paved the way for the establishment of the Teaching Council in 2006, following the Teaching Council Act of 2001. This is the statutory body responsible for the regulation of the teaching profession and the promotion of professional standards in teaching. Although there have been other pieces of education-related legislation that were enacted around the same time and in the intervening period, I contend that the implementation of these two acts has had the most significant impact on the system, on the lives of principals, teachers and pupils and on those responsible for the education of teachers, namely the colleges of education and the universities. The changes brought about by the two acts, which were implemented initially during the country's economic boom, known as the 'Celtic tiger era', and then during a period of extreme austerity within the country, have challenged societal, economic and educational systems within Ireland. They have 
also brought into question the understanding of the role of education in society and of the competences needed by practitioners within the system.

\subsection{Introduction to the Irish education system}

The Irish education system, like many other countries, comprises primary, secondary and tertiary education. The country has a population of approximately $4,609,600$ of which $23 \%$ are currently attending some form of educational institution (Central Statistics Office, 2014). There are 3,286 primary schools, catering for 536,317 pupils and 723 secondary schools, with a student population of 333,175 (Department of Education and Skills, 2014). As can be seen from these figures, there is a population bulge moving through the system at the moment, resulting in a need for increasing provision of formal education at primary and secondary levels, in the immediate and in the future.

The vast majority of primary and secondary schools are state funded but many are privately owned. $96 \%$ of primary schools are owned by religious patrons (Coolahan, Hussey, \& Kilfeather, 2012) with $52 \%$ as the corresponding percentage for the secondary sector (ESRI, 2013).

Children must attend school between the ages of 6 and 16 but in reality, most children begin school between the ages of four and five. While there is no national provision for pre-schooling in Ireland, the Irish government has invested in some provision outside of the formal education system, through private, voluntary and community interests. In 2011/12, 97\% of 4 year olds were enrolled in school, of which 58\% were enrolled in pre-primary education (Department of Education and Skills, 2015).

The majority of teenagers continue to the end of the secondary cycle, which equates to ages 17-18. Latest figures from the Department of Education and Skills (Department of Education and Skills, 2015) show that $90.6 \%$ of the cohort that entered second level education in 2008 completed the Leaving Certificate examination, a public examination held at the end of the senior cycle of secondary education in Ireland.

The third level sector has traditionally comprised Ireland's 7 universities, 14 institutes of technology and 7 colleges of education, all substantially funded by the state. There are also a number of independent private colleges in the system and a number of other third level institutions, providing specialist education in professions such as medicine and law (Department of Education and Science, 2004). In addition, the further education sector offers programmes that are not part of the third level system but occur after second level schooling, including programmes such as Post Leaving Certificate courses, second chance education opportunities, adult literacy and evening adult programmes (Department of Education and Science, 2004).

Ireland has participated in the Programme for International Student Assessment (PISA) since its inception in 2000. The most recent PISA results show that Ireland is above the OECD 
average performance in each of the three domains, with a rank of 7/64 in reading, 20/64 in mathematics and 15/64 in science (Perkins, Shiel, Merriman, Cosgrove, \& Moran, 2013). Statistics from the OECD (OECD, 2015) also show that in 2011, Ireland devoted 6.2\% of GDP to public expenditure on education. This spending appears to be mainly in the area of teacher salary. After 15 years of experience, teachers in both primary and secondary sectors can expect to have one of the highest salaries among OECD and partner countries.

The ratio of students to teachers in secondary and tertiary institutions is one of the largest among the OECD and partner countries, with a 19/1 ratio at tertiary and 15/ 1 at secondary level. Time spent teaching is comparatively large, with primary teachers teaching 915 hours per year and 735 hours per year for the secondary teacher (OECD, 2015). These figures represent class contact time and do not include the non-instruction time spent by teachers.

\subsection{Changes to the system since 1998: the establishment of a Teaching Council}

In 1998, the Education Act was passed into Irish law, paving the way for a number of changes to the Irish education landscape. Among other things, it clarified the roles and responsibilities of principals, teachers, boards of management, the school inspectorate and the Minister in relation to primary, secondary, adult and continuing education and vocational education and training. Most significantly, it provided a statutory framework for education in Ireland for the first time since the foundation of the state. This act arose from the publication of Green and White Papers and a consultative forum that gave interested citizens the opportunity to contribute to the design of the act.

The publication of the 1992 Green Paper on Education, Education for a Changing World, was a significant moment in Irish education. As the public responded to the invitation to comment on the paper, the significance of education in the lives of Irish citizens became apparent. According to Coolahan, "almost 1,000 written submissions were lodged with the Department of Education in response to the Paper" (Coolahan, 2007, p. 11). The government responded to this interest by setting up a National Education Convention, held in Dublin Castle in the autumn of 1993. Stakeholders in education made submissions to the convention and the subsequent report in January 1994 was highly influential in the construction of the White Paper, Charting our Education Future, published in 1995. One of the most significant actions resulting from the Convention and the White Paper was the decision to set up a Teaching Council, which would "give the teaching profession a degree of control over and responsibility for its own profession" (Coolahan, 1994, p. 90). This Council would replace the Secondary Teachers' Registration Council and would act as the "competent national authority for the implementation of the relevant European Union directive in relation to the mutual recognition of teacher training qualifications" (Department of Education, 1995, p. 135). The Teaching Council Act was signed into law in 2001 and the first Council was established in 2006.

Among the first actions undertaken by the newly established Teaching Council was the publication of a Code of Professional Conduct for Teachers in 2007 and a revised version in 2012. Both included standards relating to Teaching, Knowledge, Skill, Competence and 
Conduct. The consultation process that accompanied the drawing up of the initial Code took place in a climate where debates about competences and learning outcomes were taking place at both national and international levels.

\subsection{Competences and the role of learning outcomes}

In 2003, EU member states drew up the 'Common European Principles for Teacher Competences and Qualifications'. This document highlighted three broad areas of commonality for teachers, namely working with others, with knowledge, technology and information and with and in society (European Commission, 2003, p. 5). An OECD study in 2005 found that there was a general trend "towards changing requirements for teacher certification from input measures (such as number of courses taken or credit points) to output criteria, namely knowledge, skills and competences measured in multiple ways, including portfolios" (OECD, 2005, p. 115).

Although there was a move away from a more behaviourist approach to education internationally, the same could not be said of Irish education, particularly Irish higher education, at the time. As higher education in Ireland worked towards the implementation of the Bologna process at European level and the national qualifications authority (NQAI) framework within the country, this conflict became evident within the system. The ECTS users guide indicated that learning outcomes would be described "in terms of what a student is expected to know, understand and/or be able to demonstrate after completion of a process of learning', the recommended approach in higher education in the Republic is to adopt a behaviourist approach based on Bloom" (Dolan \& Gleeson, 2007, pp. 4-5). It is interesting to note that the Code of Professional Conduct $(2007,2012)$ have more in common with the OECD and ECTS understanding of learning outcomes than with a more behaviourist approach.

In addition to the Code of Professional Conduct, the first Teaching Council published a number of other policy documents during its term of office. Among these documents were:

- Teaching Council [Registration] Regulations 2009;

- Policy on the Continuum of Teacher Education June 2011;

- Initial Teacher Education: Criteria and Guidelines for Programme Providers August 2011;

- Initial Teacher Education: Strategy for the Review and Professional Accreditation of Existing Programmes September 2011.

The document relating to Initial Teacher Education criteria contains a number of learning outcome statements for graduates of the programme. These are also in keeping with a more holistic understanding of learning outcomes and are appropriate to induction into the thought process of a discipline, as described by Stenhouse (1975). 


\subsection{The PISA effect}

As mentioned earlier, Ireland's results in PISA have usually been above the OECD average. In 2009, the PISA results differed from the relatively consistent results of the three previous assessments. The first results from PISA 2009 were published in December 2010 and showed declines in rankings in two of the three domains. While the scores were still above the OECD average in both reading and science, they were below the OECD average in mathematics. Furthermore, the rankings in the three subject domains were as follows: reading 21/65, showing a drop from $5 / 56$ in 2006, mathematics 32/65, a drop from 22/57 with science showing an increase to 20/65 from 20/57 (Perkins, Moran, Cosgrove, \& Shiel, 2010; Eivers, Shiel, \& Cunningham, 2008). The Department of Education and Skills response to the PISA results clearly indicated that changes were forthcoming, or already in train, to address the decline, particularly in literacy and numeracy. The report states,

The OECD has noted that 'performance changes [in PISA] are associated with a fairly large standard error'. Irrespective of whether or not the decline in the scores on the PISA test represent a real decline in standards, the Minister for Education and Skills takes these findings seriously and is taking a proactive approach to improving literacy and numeracy standards (Department of Education and Skills, 2010, p. 1).

The report also indicated that a national plan had been launched in November 2010 to address issues of literacy and numeracy and that this plan included radical changes for teacher education. These radical changes included, among other things, an extension to the duration of Initial Teacher Education programmes to 4 years at undergraduate level and 2 years at postgraduate level, effective from 2013-14 for the Primary Teaching qualification and from 201415 for the secondary qualification (Department of Education and Skills, 2010). By June 2011, the Teaching Council had published the Criteria and Guidelines for the new ITE programmes (Teaching Council, 2011) and those responsible for the design and delivery of such programmes began the task of programme reconceptualisation and redesign.

\subsection{Reconfiguration of initial teacher education}

It is worth noting at this point that the announcement of the extension of initial teacher education programmes was made in a highly unusual manner. In 2010, a draft strategy for literacy and numeracy called 'Better Literacy and Numeracy for Children and Young People' was published by the Department of Education and Skills (2010). It contained an invitation to engage the Irish public to engage with the strategy and to respond to it. Some of the proposed actions included:

1. Setting new, higher standards for entry into initial teacher education;

2. Review the content and duration of Initial Teacher Education programmes at both primary and secondary levels;

3. Provide support to newly qualified teachers in the areas of literacy and numeracy; 
4. Provide continuing professional development opportunities for teachers in literacy, numeracy and assessment.

Responsibility for actions 1 and 2 rested with the Department of Education and Skills, the Teaching Council and the Higher Education Authority in conjunction with the providers of Initial Teacher Education. Target dates of 2012-13 for the extension of primary ITE and 201314 for secondary ITE were proposed.

In common with the production of the Green Paper on Education in 1992, the invitation to respond was welcomed and 380 interested individuals and organisations responded [see http://www.education.ie/en/Schools-Colleges/Information/Literacy-and-Numeracy/Literacyand-Numeracy-Submissions/]. Organisations such as the teacher unions, Barnardos, library associations and others published their responses, as did statutory bodies such as the National Council for Curriculum and Assessment (NCCA) and the National Council for Special Education (NCSE). Submissions were also received from the providers of Initial Teacher Education within the state.

While all respondents addressed the literacy and numeracy issues, it is unsurprising that the providers of ITE programmes responded most strongly to the proposals about the extension of the ITE programmes. In general, these responses welcomes the extension of the ITE programmes. This is also unsurprising as ITE providers had advocated such a change for many years. The extension to the duration of ITE programmes at primary level had been recommended in the report from the Primary Working Group (Report of the Working Group, 2002) but not in the report on secondary ITE, completed in the same year (Report of the Working Group, 2002). That report, in common with reports from the OECD (OECD, 1991; OECD, 2005), opted for developing the induction of newly qualified teachers rather than extending the programmes. Interestingly, the country background report that was prepared for the OECD (Coolahan, 2003) recommended an extension of the ITE programmes coupled with a structured programme of induction for new teachers on entry to the profession.

In its submission about the Literacy and Numeracy strategy, the Forum for Heads of Teacher Education in Ireland (FHTI) noted that the "proposal to increase the duration of concurrent initial primary teacher education programmes to four years, and of consecutive ITE programmes to two years is strongly welcomed. This policy change has been advocated by teacher educators for many years" (Forum for Heads of Teacher Education in Ireland, 2011, p. 1). The unusual manner of the announcement was also noted at a consultation with the ITE post-primary providers in March 2011, where the point was made that it was "strange to find major structural changes in a document on literacy and numeracy, yet there is a welcome for the structural changes proposed" (Department of Education and Skills, 2011, p. 1). Whatever the vehicle for extension of ITE, the programme providers in general welcomed it.

The literacy and numeracy strategy also indicated that changes would be made to the standards for entry into ITE programmes and this has also commenced. Entry into consecutive 
secondary teacher education programmes for the academic year 2015 now requires specific modular requirements as part of the undergraduate degrees while work continues on the entry requirements for concurrent degrees.

As ITE providers commenced the work of redesigning their programmes to meet both the requirements of the Teaching Council and the relevant Higher Education Institution (HEI), the Department of Education and Skills commissioned a report on the structure and provision of ITE in Ireland. The impetus for this came from a recognition that there were 19 state funded, and 3 private, providers of ITE offering in excess of 40 ITE programmes. The review comprised an international panel led by Pasi Sahlberg, the Finnish educationalist. The panel met with ITE providers and with relevant personnel from the HEIs and published the results of their review in the summer of 2012. Key recommendations included the reduction of the number of programmes, strategic restructuring of programme providers into six configurations encompassing the full range of sectoral teacher education from early childhood through to adult education (Department of Education and Skills, 2012). In most instances, this required ITE programme providers to plan not only for the design of a new ITE programme but for restructuring of the Department/School of Education. The ambition of the review was that "by 2030 Ireland will have a network of teacher education institutions based on a small number of internationally comparable institutes for teacher education" (Department of Education and Skills, 2012, p. 24) and will offer programmes in both ITE and CPD. At the time of writing, much has been done on bringing together the component parts for these institutes but it is important to note that it is an additional change to at a time of already significant change to ITE in Ireland.

\subsection{Induction in Ireland - phase two of the continuum}

As mentioned earlier, the Teaching Council published a Policy on the Continuum of Teacher Education in June 2011. It outlined the significance of the three I's, namely initial, induction and in-career development, in the working life of the teacher. In addition, the Council adopted another three I's to underpin all stages of the continuum; innovation, integration and improvement (Teaching Council, 2011). The section of the Teaching Council Act relating to induction was commenced on September $1^{\text {st }} 2012$ and the delivery of the induction programme was undertaken by the National Induction Programme for Teachers (NIPT). Induction programmes for newly qualified teachers had been running in the country since the introduction of a pilot programme in 2002. This programme, the National Induction Pilot Programme for Teachers (NIPPT), had began in 2002 as a result of a partnership initiative between the Department of Education and Science, the three teacher unions and the ITE providers. At primary level, the programme was housed in St Patrick's College, Drumcondra, Dublin, one of the primary ITE colleges, while the secondary programme operated from the School of Education in University College Dublin, which was one of the providers of ITE for the secondary system. Both programmes operated independently on the ground within their sectors but had a common national steering committee and common underlying principles. There was a commitment to a whole school approach, to working with School Principals and to training mentors to work with the newly qualified teachers (NQTs). It appears that the initial intention 
was to complete the pilot programme after 3 years, as evidenced by a comment in 2005 from the then Minister for Education, Mary Hanafin, who commented that she looked forward to considering the final Report of the recently completed National Pilot Project on Induction (Hanafin, 2005); however, the pilot project continued for a further five years with funding confirmed on a year-by-year basis.

By September 2010, NIPT was established and responsibility for the delivery of induction workshops was delegated to them. NIPT worked with the Teaching Council in the development of induction in the country, both prior to and subsequent to the commencement of Section 7 (2) (f) and (g) in September 2012.

In January 2012, the Teaching Council consulted stakeholders on its proposed Career Entry Professional Programme (CEPP) but this proposal caused much concern within the education community and was significantly amended as a result of the consultations. A new model was drawn up and in September 2013, after further consultation with stakeholders, the Teaching Council introduced a new model of induction and probation as a pilot programme to run from September 2013 to 2016 (Teaching Council, 2012). This model contains the workshops developed by the NIPT but increases significantly the role of the school in the induction and probation of new members into the profession. The secondary schools became involved but initially the Irish National Teachers Organisation (INTO), the union for primary teachers, instructed its membership not to be involved in the pilot programme. In December 2014, the pilot project has 150 schools and 190 NQTs involved in the project (Teaching Council, 2012).

\subsection{In career development - the third phase of the continuum}

The third component of the continuum, continuous professional development for teachers, has now come to the fore. The Teaching Council recently issued an invitation for suggestions about the development of a national framework for CPD in Ireland (Teaching Council, 2014). This invitation was issued in the first instance to the registered teachers only and took the form of

1. consultation workshops

2. an on-line questionnaire for individual teachers

3. school-based meetings.

This first phase of the consultation was completed on January $16^{\text {th }}, 2015$. The next phase of the process involves the collation of the feedback with a view to designing the first draft of the framework. This will then go to teachers and to the stakeholders for further consultation before the publication of a CPD framework in March 2016.

The amount of change within the education sphere has been significant since the commencement of the Education Act in 1998. But the changes to the profession of teaching have been even more significant since the first Teaching Council came into being in 2006. In 
the eight years since its inception, there have been significant changes made in relation to teaching in Ireland. All ITE programmes have now been reviewed, accredited and extended. Induction workshops are now mandatory for all NQTs and, with the commencement of Section 30 of the Teaching Council Act in September 2014, all teachers at primary and secondary levels within the state who are paid from state funds are registered with the Teaching Council. The vast majority of the changes have been brought about through consultation with stakeholders and the effect of these consultations can be seen in the differences between draft and final versions of many of their policies.

\subsection{Curricular changes and the new Junior Cycle programme}

Concurrent to the implementation of changes to the structure of the teaching profession in Ireland was another change, namely a change to the Junior Cycle Programme in secondary schools. In November 2011, the National Council for Curriculum and Assessment (NCCA), a statutory body responsible for advising the Minister, published a framework for Junior Cycle, including a change to the assessment processes currently used as part of the Junior Cycle. The document, 'Towards a Framework for Junior Cycle - Innovation and Identity', was developed in consultation with stakeholders in the system and clearly indicated that changes to all other parts of the programme was dependent on a change to the mode of assessment, particularly the reliance on a state-administered terminal examination (NCCA, 2011). In 2012, the Minister for Education and Skills, Ruairi Quinn, announced the radical reform of the Junior Cycle with the changes to be introduced to students on an incremental basis from September 2014 (Department of Education and Skills, 2012).

Although this chapter has not taken curricular change within the schools as a focus, this change is particularly significant in Irish education. It occurs in a climate of austerity, where posts of responsibility were cut within schools and teacher salaries were reduced as part of a national plan. Not only does it affect the tradition of a state examination at the end of the Junior Cycle of education, its introduction coincided with the introduction of the extended ITE programmes at second level and with the development of the pilot programme for induction. The Junior Cycle changes were, and still are, highly contested. To date, two strike days have been called by the teacher unions and attempts at mediation between the Department of Education and Skills and the teacher unions are at a standstill. In the current climate of austerity within Ireland, the number of changes appears to have been too much for the teaching population to contend with. Yet the irony is that in many schools, the developmental work continues. Pilot schools for the Induction programme continue their work, experienced teachers engage in the development of student teachers, work goes on in relation to developing assessment for and of learning within schools and classrooms. While the national picture is one of unrest, not just in the education sphere but in other areas of life as well, there also appears to be a sense of 'getting on with it' in many aspects of working life. 


\subsection{Challenges and opportunities for educationalists}

Fullan (1991) described the change process as having four broad phases: initiation, implementation, continuation and outcome. While changes do not occur in a linear fashion, with one change completed and institutionalised before the next change is initiated, it is worth considering the changes within Irish education at the moment and the phase within which each finds itself at this moment in time.

Changes to ITE programmes and to the institutional structures supporting them lie somewhere between initiation and implementation, as does the new process of induction of newly qualified teachers. CPD is at a pre-initiation stage, with consultation as part of the initiation process. Junior cycle changes are stalled somewhere between initiation and implementation. This points to a system that is heavily loaded at the initiation and implementation stages where a number of the changes are strongly both interlinked and dependent on the same group of educators to implement the changes. Yet it is natural that these changes, particularly to the profession, would occur synchronously. As the requirements for entry to programmes change, the programmes are longer and more costly, and the exit award is at the masters level for consecutive programmes, it is understandable that the induction into the profession is also experienced in a structured and professional manner. Teachers who now take a role in induction into the profession also need opportunities to up skill and to have their professional development recognised in a formal manner. It gives a real opportunity for the profession to take upon itself a responsibility for who enters the profession and to have a clear part to play in that decision. As student teachers spend more time in schools, it gives experienced teachers a real opportunity to involve themselves in educating the profession and to become teacher educators in the first order setting of the school.

With every opportunity comes a challenge or a constraint. In this instance, the biggest concern with the change to ITE lies in the areas of equality and diversity. While the Finnish model of extended ITE programmes at the masters level is lauded, one must also look at the ways in which this model is funded. Those who choose to become teachers will have fees paid and will receive a stipend while they study. For me, this is an important part of the pre-service induction into the profession as it allows those who will enter the profession to do so in a focused manner from the very beginning. In Ireland, the concurrent programmes currently have total fees of $€ 10,800-€ 12,000$ across the two years. Due to public funding of the fees for undergraduate programmes, students on concurrent programmes incur much smaller costs. The change in policy could potentially result in concurrent programme teacher education becoming the programme of choice for the potential teacher. This financial burden will also affect those who decide to enter teaching as a second career as they typically have other financial commitments, such as mortgages and families, at that stage of their lives. When the Education Department of NUI Maynooth responded to the Literacy and Numeracy Strategy, one of the points made concerned the potential reduction in diversity within the teaching population.

As teacher education courses are extended to 2 years duration, the cost to student teachers, in terms of fees, and in lost earnings, are increased. It would be 
regrettable if, as a consequence, teaching became less accessible to those from less wealthy families. Care should be taken to ensure that the extended duration of the programmes is matched by availability of grants and other supports to ensure equitable access to the profession from a diversity of backgrounds (Education Department NUI Maynooth, 2011, p. 4)

Although grants such as the Back to Education grant and Student Universal Support Ireland are available, early indications from the first student cohort on the 2 year programmes points to the awarding of very small grants that in most instances cover only $30 \%$ of fees. Graduates face the prospect of beginning their work as teachers with substantial debt accrued, a reduced starting salary and a lack of full time teaching jobs available.

Another area of concern lies with the current induction model involving attendance at a prescribed number of workshops over the course of the year. In the absence of employment opportunities for NQTs, some find themselves attending the workshops while unemployed, others while teaching on temporary / part-time contracts with little consistency and a third group who have emigrated but return to attend these workshops as part of their requirement for registration. Some induction models, such as that used in the Scottish system, offer an induction year where the NQT is placed with a particular school, is given a timetable amounting to $70 \%$ of a full teaching timetable and is offered support both at school and at national level. The introduction of such a strategy would serve two purposes; it would allow the NQT to consolidate what $\mathrm{s} /$ he has learned in ITE and it would ensure that there is an income for the first year which could be used to alleviate some of the debt accrued during the ITE programme.

\subsection{Thinking about the future}

As mentioned earlier, we are at initiation and implementation stages of the change process in many structures within the education system in Ireland. Where will these changes be in 5 years or in 10 years time? Will we be at the continuation stage, where the changes have become institutionalised and the twin processes of initiation and implementation are distant memories? What needs to happen over the next five years in order for the changes to become institutionalised?

Some of the factors have already been mentioned in the previous section. There is a need to think systematically about the impact of the changes on the system and the individuals therein. Structured funding opportunities are necessary, as are structures that support the NQT in finding teaching work in the years post-qualification.

As the economic future begins to brighten, the lessons we learned in the aftermath of the Celtic tiger need to be taken on board. A significant percentage of GDP needs to be earmarked for education. Meaningful career development prospects need to be developed for the teaching profession. We need to find ways to learn from our returning emigrants and the things that they have learned while teaching in other countries and other systems. Above all, we need to remember that the use of consultative processes in the design of policy is critical to the continued democratic development of education in Ireland. 


\section{REFERENCES}

Central Statistics Office. (2014, August 26). Central Statistics Office. Retrieved from http://www.cso.ie/en/releasesandpublications/er/pme/populationandmigrationestimate sapril2014/\#.VP3hnWZhRpk

Coolahan, J. (1994). Report on the national education convention. Dublin: NEC Secretariat.

Coolahan, J. (2003). Country background report on the teaching career in Ireland. Dublin: Department of Education.

Coolahan, J. (2007). A review paper on thinking and policies relating to teacher education in Ireland. Maynooth: Teaching Council.

Coolahan, J., Hussey, C., \& Kilfeather, F. (2012). The forum on patronage and pluralism in the primary sector: Report of the forum's advisory group. Dublin: Government of Ireland.

Department of Education. (1995). White paper: Charting our education future. Dublin: Government of Ireland

Department of Education and Science. (2004). A brief description of the Irish education system. Dublin, Ireland: Government of Ireland.

Department of Education and Skills. (2010). Better literacy and numeracy for children and young people. Dublin: Department of Education.

Department of Education and Skills. (2010, December 7). OECD PISA products. Retrieved from http://www.oecd.org/pisa/pisaproducts/46971917.pdf

Department of Education and Skills. (2011, March 29). Draft national plan to improve literacy and numeracy in schools consultation with initial teacher education providers (Post Primary). Retrieved from http://www.education.ie/en/SchoolsColleges/Information/Literacy-and-Numeracy/Literacy-and-NumeracySubmissions/?pageNumber $=29$

Department of Education and Skills. (2011). Literacy and numeracy for learning and life: The national strategy to improve literacy and numeracy among children and young people. Dublin: Government of Ireland.

Department of Education and Skills. (2012, July 30). 1 report of the international review panel on the structure of initial teacher education provision in Ireland: Review conducted on behalf of the Department of Education and Skills. Retrieved from https://www.education.ie/en/Press-Events/Press-Releases/2012- Press-Releases/PR1210-04.html

Department of Education and Skills. (2012, October 4). Department of Education and Skills press releases. Retrieved from https://www.education.ie/en/Press-Events/PressReleases/2012-Press-Releases/PR12-10-04.html

Department of Education and Skills. (2014, June 30). Department of Education and Skills. Retrieved from https://www.education.ie/en/Publications/Statistics/Key-Statistics/

Department of Education and Skills. (2014). Education at a glance 2014: A country profile for Ireland. Dublin: Government of Ireland . 
Department of Education and Skills. (2015). Retention rates of pupils in second level schools 2008 entry cohort. Dublin: Government of Ireland.

Dolan, R., \& Gleeson, J. (2007). The competences approach to teacher professional development: Current trends and future prospects. Armagh: SCoTENS.

Education Department NUI Maynooth. (2011, January 30). Literacy and numeracy submissions. Retrieved from http://www.education.ie/en/SchoolsColleges/Information/Literacy-and-Numeracy/Literacy-and-NumeracySubmissions/?pageNumber $=5$

Eivers, E., Shiel, G., \& Cunningham, R. (2008). Ready for tomorrow's world? The competencies of Irish 15-year-olds in PISA 2006 summary report. Dublin: Educational Research Centre.

ESRI. (2013). Governance \& funding of second-level schools in Ireland. Dublin: ESRI.

European Commission. (2003). Common european principles for teacher competences and qualifications. Brussels.

Forum for Heads of Teacher Education in Ireland. (2011, February 28). Literacy and numeracy submissions. Retrieved from http://www.education.ie/en/SchoolsColleges/Information/Literacy-and-Numeracy/Literacy-and-NumeracySubmissions/?pageNumber $=3$

Fullan, M. (1991). The new meaning of educational change. London: Cassell Educational Limited.

NCCA. (2011, November 30). NCCA Innovation and identity. Retrieved from http://ncca.ie/framework/doc/NCCA-Junior-Cycle.pdf

OECD. (1991). Reviews of national policies of education. Paris: OECD.

OECD. (2005). Teachers matter: Attracting developing and retaining effective teachers. Paris.

OECD. (2015, March 2). Education GPS. Retrieved from http://gpseducation.oecd.org/Home

Perkins, R., Moran, G., Cosgrove, J., \& Shiel, G. (2010). PISA 2009: The performance and progress of 15-year-olds in Ireland summary report. Dublin: Educational Research Centre.

Perkins, R., Shiel, G., Merriman, B., Cosgrove, J., \& Moran, G. (2013). Learning for life: The achievements of 15 - year - olds in Ireland on mathematics, reading literacy and science in PISA 2012. Dublin: Educational Research Centre.

Report of the Working Group. (2002). Preparing teachers for the 21st century. Dublin.

Report of the Working Group. (2002). Report of advisory group on post-primary teacher education. Dublin: Department of Education and Skills.

Stenhouse, L. (1975). An introduction to curriculum research and development. Portsmouth: Heinemann Educational Publishers.

Teaching Council. (2012, March 7). Droichead pilot. Retrieved from http://www.teachingcouncil.ie/en/Teacher-Education/Droichead/

Teaching Council. (2011). Initial teacher education: criteria and guidelines for programme providers. Maynooth: Teaching Council.

Teaching Council. (2011). Policy on the continuum of teacher education. Maynooth: Teaching Council. 
Teaching Council. (2014, November 30). Consultation process. Retrieved from http://www.teachingcouncil.ie/en/Teacher-Education/Continuing-ProfessionalDevelopment/ 